\title{
The Impact of Promotion Justice on Job Performance and Organizational Citizenship Behavior: The Mediating Role of Trust
}

\author{
Qingjuan Wanga ${ }^{a}$ Ailing Wang ${ }^{b}$ and Rui $\mathrm{Li}^{\mathrm{c},{ }^{*}}$ \\ College of Tourism \& Service Management, Nankai University, Tianjin, China \\ awqingjuan@nankai.edu.cn, b574205044@qq.com, c2414714512@qq.com
}

${ }^{*}$ Corresponding author

\begin{abstract}
Keywords: Promotion Justice, Job performance, Organizational Citizenship Behavior, Trust.
\end{abstract}
\begin{abstract}
It is acknowledged that promotion is not only an important way for employees to achieve their career goals but also an effective means of organization incentives. This study explores the impact of promotion justice on job performance and organizational citizenship behavior(OCB) as well as its mechanism. Results show that promotion justice affects job performance and OCB, and trust serves as a mediating variable.
\end{abstract}

\section{Introduction}

Since Greenberg first proposed the concept of organizational justice in 1987, existing research in this field is more extensive. Promotion justice, by contrast, has received little attention among domestic and foreign scholars. Promotion is an important way for employees to achieve their career goals, including both the upwards and lateral mobility. The perceived fairness in promotion is of vital importance to organizations. Unlike external selection, internal candidates who fail their promotion will remain in the organization and have a profound impact on day-to-day operations and future development of their organizations. If these candidates feel that they have been treated unfairly in promotion process, this unfairness perception will seriously affect their job performance, greatly reduce $\mathrm{OCB}$, and even make them want to leave their jobs.

Trust, as an important social relationship, exists not only in our daily lives, but also in organizations, and can become one of the key determinants of success of both the employees and corporates. According to Zucker, trust is derived from formal and informal mechanisms, among which the formal mechanism refers to formal systems such as legal contracts and social norms, and the latter focuses more on interactions between people ${ }^{[1]}$. Likewise, trust in organizations comes from the same ways. Especially in the promotion process, when internal candidates perceive fairness either from formal promotion systems and promotion results, or from interpersonal interactions with supervisors and promotion reviewers, they will foster sense of trust towards organizations and managers. This sense of trust will make them believe that they are now guided by trustful organizations and leaders, thus generating a strong sense of belonging towards organizations. As a result, they are motivated to perform more positive behaviors psychologically, including improving job performance and performing $\mathrm{OCB}$, making them be willing to contribute and be more responsible for the organizations. Based on this, the purpose of this study is to explore the mediating role of trust in the impact of promotion justice on job performance and OCB and help organizations better understand the mechanism of fairness perception under promotion context.

\section{Promotion justice}

As a crucial internal selection method, successful promotion not merely brings material feedback to employees, but also helps them meet their spiritual needs. Consequently, it is especially important to effectively identify employees' fairness perceptions in the context of promotion. The concept of promotion justice can be dated back to organizational justice, first proposed by McEnrue in 1989. Drawing on the theory of organizational justice, McEnrue identified the factors that influence fairness perception in the process of promotion from the perspective of distributive justice and procedural 
justice $^{[2]}$. Ford et al., however, based on Gilliland's research in the field of applicant reactions, divided applicant reactions in the promotion context into procedural justice and distribution justice, among which the promotion procedural justice refers to employees' perception of the formal characteristics of process, the explanation of the procedure and decision-making process, and the interpersonal treatment in the procedure ${ }^{[3]}$.

Since internal employees have been working in the organization before and after promotion, they possess a good deal of information about their organizations and have contributed more for a long time. Consequently, it's no wonder that their reactions to the unfair promotion are much more stronger ${ }^{[4]}$, and followed by negative behaviors and intentions, such as reducing job satisfaction, organizational commitment and job performance, performing turnover intention, and even adversely affecting their physical and mental health. However, existing researches on the impact of promotion justice on job performance and OCB are still limited. Under this circumstance, this study attempts to explore the impact of promotion justice on job performance and OCB as well as the mediating role of trust.

\section{Promotion justice and job performance}

Job performance is a combination of various work output that employees perform at their work, which is not only result-oriented but also a behavioral process. Campbell defines job performance as the degree to which an employee helps his organization achieve its goals ${ }^{[5]}$. Motowidlo et al., on the other hand, pointed out that job performance is the cumulative value that an employee's independent actions bring to organizations over a certain period of time, and it is behavioral, fragmentary, evaluative and multi-dimensional ${ }^{[6]}$. According to current mainstream view, job performance is composed of task performance and contextual performance ${ }^{[6,7,8]}$. More specifically, Task performance mainly refers to the effectiveness of employees contributing to the organization by completing the actual work, while contextual performance is more about achieving effective output through extrarole behaviors.

There are abundant literatures in the fields of organizational justice and selection justice that explore the relationship between fairness perception and job performance. Konradt et al. used a longitudinal method to study the impact of procedural justice and fairness expectation on a variety of outcomes at different time during the selection process. It was found that after test and before feedback, procedural justice is positively related to employee's long-term job performance ${ }^{[9]}$. Research by McCarthy et al. also supports the positive impact of procedural justice on job performance ${ }^{[10]}$. In the context of promotion, promotion justice also exerts great influence on job performance. Wan et al. interviewed managers of several multinational companies in Malaysia and found that if employees feel unfair in the process of promotion, their job performance will be negatively affected ${ }^{[11]}$. In brief, if employees perceive fairness in promotion procedures and results, they will tend to be more responsible and spend more time and energy on their work, thus effectively improve their job performance. Conversely, an unfair perception of the promotion process and results will cause employees to significantly reduce their own investment, resulting in a decline in performance. To sum up, this study puts forward following propositions:

\subsection{Proposition 1}

Employees' perceptions of procedural justice in promotion will have a positive impact on job performance.

\subsection{Proposition 2}

Employees' perceptions of distributive justice in promotion will be positively related to job performance 


\section{Promotion justice and $\mathrm{OCB}$}

OCB can be regarded as a kind of extra-role behavior, which can serve as an effective lubricant to promote organizational output to a certain extent. The concept of OCB was originally proposed by Smith and Organ in 1983, who pointed out that OCB mainly included two dimensions: Altruism and Generalized Compliance. OCB enables flexible handling with accidents that occur at work, is generated by a non-contractual mechanism, and is difficult to measure by organization's performance appraisal system ${ }^{[12]}$. Based on this, Borman et al. define OCB as arbitrary extra-role behavior designed either to help organization members or to comply with organizational rules and regulations ${ }^{[7]}$.

Employees' fairness perception of promotion procedures and outcomes can have an impact on OCB. From the perspective of applicants reaction model, McCarthy et al. proposed that the differences in the identity of internal and external candidates will make significant differences to their behaviors, and a series of outcome such as job satisfaction and OCB are affected as well ${ }^{[4]}$. In the applicants reaction model under promotion circumstances, Ford et al. viewed OCB as an important behavioral outcome of fairness perception, pointing out that the more fair the promotion procedures and outcomes employees perceive, the more OCB they will perform ${ }^{[3]}$. Xiao Xingzheng and Zhao Zhibin investigated employees of liquor companies in the form of questionnaires in China, and results indicated that perceptions of promotion opportunities and promotion justice are positively associated with $\mathrm{OCB}^{[13]}$. In brief, if employees perceive that the promotion process and results are fair, in addition to maintaining their good job performance, they will voluntarily perform more OCB such as generously providing more help to colleagues and more consciously abide by the company's various rules. In summary, following propositions are advanced:

\subsection{Proposition 3}

Employees' perceptions of procedural justice in promotion will have a positive effect on OCB.

\subsection{Proposition 4}

Employees' perceptions of distributive justice in promotion will be positively associated with OCB.

\section{Mediating role of trust}

Trust is a concept that covers psychology, economics, sociology, ethics, and management, making itself a complicated notion. From the perspective of management, Mayer et al. argued that trust is the willingness to afford the hurt of others, which is based on the expectation that others will make favorable behaviors for them in the future, regardless of their ability to control the other party ${ }^{[14]}$. This definition coincides with the social exchange theory ${ }^{[15]}$. It is believed by scholars in the field of social exchange theory that people exchange certain resources with each other to invest in better interpersonal relationships, and one of the important conditions for social exchange is trust.

Extensive researches have demonstrated that employees' perceived fairness in organization will influence their sense of trust. After studying the relationship between organizational justice, organizational trust and corporate cohesion in China, Sun Meijia et al. found that except that distributive justice of employees makes no difference to trust on colleagues or subordinates, procedural justice, distributive justice and interactive justice have significant influence on system trust, leadership trust and trust on colleagues or subordinates ${ }^{[16]}$. In addition, Wong et al. also pointed out that in China's state-owned enterprises and joint ventures, all three dimensions of organizational fairness have a positive impact on employees' trust in organization and leadership ${ }^{[17]}$.

Employees' trust in organization and leadership also affects their subsequent behavioral variables. Relevant studies have confirmed this. Wang Feifei et al. studied the impact of trust mechanism on OCB from the perspective of human resource structure, and found that systematic, cognitive and emotional trust significantly affect OCB of job-based, contract-based and knowledge-based employees ${ }^{[18]}$. Study by Wong et al. also demonstrated the impact of trust on OCB of Chinese stateowned enterprises and joint venture employees ${ }^{[17]}$. Research in the impact of trust on employees' job performance is relatively limited, but this study believes that trust also affects job performance. When 
employees lose trust in organizations and managers, they are more likely to make negative behaviors, such as sabotage, absenteeism, and inefficiency, thus affecting their job performance and reducing their voluntary investment in organizations.

Above analysis indicates that trust may play a mediating role in organizational justice and job performance and OCB. A lot of studies have confirmed this ${ }^{[15,17,19]}$. In the context of promotion, trust may have the same effect. When employees believe that the promotion procedures and results are fair, they will trust organizations and managers and believe that they will lead themselves to grow better, thus becoming more efficient, active, and studious, and improving their job performance. Moreover, they will be eager to help colleagues and customers, consciously abide by the organization's various rules and regulations, and safeguard the interests of the organization, performing more OCB. To sum up, following proposition is presented:

\subsection{Proposition 5}

Trust plays a mediating role in promotion justice and job performance and OCB.

\section{Conclusion}

Based on above analysis, this study explores how promotion justice affects employees' job performance and $\mathrm{OCB}$, and analyzes the mediating role of trust. Findings are as followed. Firstly, internal applicants' perceived procedural and distributive fairness in promotion can have an effect on their job performance and OCB. Secondly, trust serves as a mediating variable between promotion justice and job performance and OCB.

In the process of promotion, how to ensure transparency and fairness of the promotion system procedures, thus guiding employees to make more contributions to the organization, is worthy of consideration for each organizations and managers. This research has the following enlightenment. First, enterprises should pay more attention to the justice of the promotion procedures and systems, so that employees can experience unbiased treatments from organizations and managers. Second, enterprises should focus more on cultivating employees' trust in organizations and managers, which can in turn form a corporate culture of mutual trust. Third, OCB plays an important role in the development and growth of organizations as well as job performance, and managers should place equal weight on OCB. This study is a theoretical analysis of the impact of fairness perception on job performance and OCB in the context of promotion, and remains to be confirmed by empirical research.

\section{Acknowledgment}

This research is supported by grants from the National Natural Science Foundation of China (grant number 71572086).

\section{References}

[1] L. G. Zucker, Production of Trust: Institutional Sources of Economic Structure, 1840-1920, Research in organizational behavior, Vol. 8. Greenwich, Conn.: JAI Press, 1985.

[2] M. P. McEnrue, The perceived fairness of managerial promotion practices, Human Relations, vol. 42, pp. 85-827, 1989.

[3] D. Ford, D. M. Truxillo, and T. N. Bauer, Rejected But Still There: Shifting the Focus in Applicant Reactions to the Promotional Context, International Journal of Selection \& Assessment, vol. 17, pp. 402-416, 2009.

[4] J. M. McCarthy, T. N. Bauer, and D. M. Truxillo, et al., Applicant Perspectives During Selection: A Review Addressing "So What?," "What's New?," and "Where to Next?", Journal of Management, vol. 43, pp. 1693-1725, 2017. 
[5] J. P. Campbell, Some possible implications of "modeling" for the conceptualization of measurement, In F. Landy, S. Zedeck, \& J. Cleveland(Eds), Performance measurement and theory(pp. 277-298). Hillsdale, NJ: Lawrence Erlbaum Associates, Inc, 1983.

[6] S. J. Motowildo, W. C. Borman, and M. J. Schmit, A Theory of Individual Differences in Task and Contextual Performance, Human Performance, vol. 10, pp. 71-83, 1997.

[7] W. C. Borman and S. J. Motowidlo, Task performance and contextual performance: the meaning for personnel selection research, Human Performance, vol. 10, pp. 99-109, 1997.

[8] D. S. Kiker and S. J. Motowidlo, Main and interaction effects of task and contextual performance on supervisory reward decisions, Journal of Applied Psychology, vol. 84, pp. 602-609, 1999.

[9] U. Konradt, Y. Garbers, and M. Böge, et al., Antecedents and Consequences of Fairness Perceptions in Personnel Selection: A 3-Year Longitudinal Study, Group \& Organization Management, vol. 42, pp. 113-146, 2017.

[10]J. M. McCarthy, C. H. Van Iddekinge, and F. Lievens, et al., Do candidate reactions relate to job performance or affect criterion-related validity? A multistudy investigation of relations among reactions, selection test scores, and job performance, Journal of Applied Psychology, vol. 98, pp. 701-719, 2013.

[11]H. L. Wan, M. Sulaiman, and A. Omar, et al., Procedural justice in promotion decisions of managerial staff in Malaysia, Asia Pacific Business Review, vol. 18, pp. 99-121, 2012.

[12]C. A. Smith, D. W. Organ, and J. P. Near. Organizational citizenship behavior: Its nature and antecedents, Journal of Applied Psychology, vol. 68, pp. 653-663,1983.

[13]X. Z. Xiao and Z. B. Zhao, Does the employee who perceives promotion be more selfless? An empirical study of the relationship between promotion perception and organizational citizenship behavior, Human Resources Development of China, No. 3, pp. 90-97, 2017.(In Chinese)

[14]R. C. Mayer, J. H. Davis, and F. D. Schoorman. An integrative model of organizational trust. Academy of Management Review, vol.20, pp.709-734, 1995.

[15]J. A. Colquitt, B. A. Scott, and J. B. Rodell, et al. Justice at the Millennium, a Decade Later: A Meta-Analytic Test of Social Exchange and Affect-Based Perspectives, Journal of Applied Psychology, vol.98, pp.199-236, 2013.

[16]M. J. Sun and X. Cui, Cultural traits of organizational justice and organizational trust and their impact on the formation of Chinese corporate cohesion, Chinese Journal of Management, vol. 10, pp. 1462-1469, 2013.(In Chinese)

[17]Y. T. Wong, H. Y. Neo, and C. S. Wong, Perceived organizational justice, trust, and OCB: A study of Chinese workers in joint ventures and state-owned enterprises, Journal of World Business, vol. 41, pp. 344-355, 2006.

[18]F. F. Wang and S. T. Zhang, An Empirical Study of the Impact of Trust Mechanism on Organizational Citizenship Behavior: Based on the Perspective of Human Resource Structure, Journal of Dalian University of Technology(Social Sciences), vol. 38, pp. 114-118, 2017.(In Chinese)

[19]S. Aryee, P. S. Budhwar, and Z. X. Chen, Trust as a mediator of the relationship between organizational justice and work outcomes: Test of a social exchange model, Journal of Organizational Behavior, vol. 23, pp. 267-285, 2002. 